\title{
The Law and Society in the Old Testament: Formulation and Implementation of the Law in Ancient Israel
}

\author{
Temba Rugwiji (University of Pretoria, South Africa)
}

\begin{abstract}
Various laws were practised in ancient Israel. Although the present study will introduce briefly the concept of law as practised in Ancient Near East (ANE) in general, the project focuses particularly on ancient Israel as depicted by the Old Testament (OT) law traditions. The study seeks to investigate two main issues, namely: (1) formulation and implementation of the laws in ancient Israel, and (2) the application of the OT laws during the New Testament (NT) era and in Christendom. An attempt is made to respond to the following three research questions: (1) how were the OT laws formulated and implemented? (2) Were the OT laws the same as those practised by pagan nations or kings? (3) what is the NT/Christian view of the OT laws? In its entirety, the discourse will utilise two approaches, namely: (1) narrative inquiry, and (2) desk research.
\end{abstract}

KEYWORDS: Legal traditions, Ancient Israel, Old Testament, New Testament.

\section{A INTRODUCTION}

The OT presents various laws given to Moses by Yahweh. As Eben Scheffler (among other scholars ${ }^{1}$ ) observes, "The Pentateuch contains indications of an extensive legal system in ancient Israel." ${ }^{.2}$ David Dorsey provides a total of about

* Submitted: 24/12/2018; peer-reviewed: 22/01/2020; accepted: 11/02/2020. Temba Rugwiji, "The Law and Society in the Old Testament: Formulation and Implementation of the Law in Ancient Israel", Old Testament Essays 33 no. 1 (2020): 125 - 142. DOI: https://doi.org/10.17159/2312-3621/2020/v33n1a8.

1 See for example, Jonathan Burnside, God, Justice and Society: Aspects of the Law and Legality in the Bible (Oxford: Oxford University Press, 2011), n.p; Raymond Westbrook \& Bruce Wells, Everyday Law in the Biblical Israel: An Introduction (Westminster: John Knox Press, 2009), n.p; Cheryl B. Anderson, Ancient Laws and Contemporary Controversies (Oxford Univ. Press, 2009), n.p; Richard H. Hiers, Justice, and Compassion in the Biblical Law (Bloomsbury: T\&T Clark, 2009); Fred G. Zaspel, "Divine Law: A New Covenant Perspective," Reformation and Revival 6/3 (Summer 1997):145-69; Dennis M. Swanson, "Introduction to New Covenant Theology", TMSJ 18/1 (Fall 2007): 149-163; Albrecht Alt, "The Origin of Israelite Law," in Essays on Old Testament History and Religion, 79-132 (Oxford: Oxford University Press, 1996), n.p.

2 Eben H. Scheffler, Politics in Ancient Israel (Pretoria: Biblia Publishers, 2001), 18. 
613 laws given to Israel by Yahweh at Mount Sinai. ${ }^{3}$ Available ancient religious texts do not provide specific models on the formulation of these laws. The Decalogue (Exod. 20:3-17) given to Israel by Yahweh at Mount Sinai comprised a set of ten laws that were civil, ceremonial and moral in character by which Israel was going to live in the Promised Land. Fundamentally, the biblical narratives and laws express esteem for life. ${ }^{4}$ For example, the Jewish law prohibited eating and drinking of blood (Gen. 9:4-5; Lev. 7:26-27). ${ }^{5}$ Both Psalms 27:2 and Zechariah 11:9 did not approve of eating human flesh. Civil laws included deployment of justice and human rights. Nehemiah, for example, introduced necessary administrative/social justice reforms (Neh. 5:6-18) for a postexilic Judean society. ${ }^{6}$ In the NT as well, some glimpses are portrayed of kings ${ }^{7}$ who executed judgment on the basis of perceived violation of customary laws among the Jews. Although Christians read the OT laws as also binding in their "journey of faith", not many practically adhere to the stipulations of these laws. This conversation examines the OT law traditions in order to establish the utilisation of such laws by the ancient Israelite society.

\section{B STATEMENT OF THE PROBLEM}

The present study was rekindled by a renewed reading of David Dorsey's research. ${ }^{8}$ Equally important was my familiarisation with a more recent investigation by Francis Machingura and Godfrey Museka. ${ }^{9}$ Both studies have illuminated a complementary, yet divergent thrust on the OT laws. However, although the above studies have succeeded in fostering a discussion on the OT laws in ancient Israel for today's Christians, one should not be oblivious of the link which is lurking with regards to the utilisation of the OT laws by pagan kings in ancient Israel and the application of these laws in the Christendom era. In an attempt to solve the aforementioned problem, this research seeks to respond to the following three research questions: (1) how were the OT laws formulated and implemented? (2) Were the OT laws the same as those practiced by pagan nations or kings? (3) what is the NT/Christian view of the OT laws?

3 David Dorsey, "The Law of Moses and the Christians: A Compromise," JETS 34/3 (1991): 321.

4 Francis Machingura and Godfrey Museka, "'Blood as the Seat of Life': The Blood Paradox among Afro-Christians," Perichoresis 14/1(2016):42.

5 See Machingura and Museka, "'Blood as the Seat of Life,", 43

6 Temba Rugwiji, “Appropriating Judean Postexilic Literature in a Postcolonial Discourse: A Case for Zimbabwe," (PhD thesis, University South Africa, Pretoria, 2013), 203.

7 For example, Herod (Luke 23:11), Festus (Acts 25:9) and Agrippa (Acts 26:2).

8 See Dorsey, "The Law of Moses and the Christians," 321-334.

9 See Machingura and Museka, "Blood as the Seat of Life," 41-62. 


\section{METHODOLOGY}

The present study will utilise two approaches, namely: (1) narrative inquiry and (2) desk research. Narrative inquiry largely looks at the narratives surrounding the legal traditions in ancient Israel, while desk research utilises the internet, book chapters, and journal articles. ${ }^{10}$

\section{FORMULATION AND IMPLEMENTATION OF LAWS IN ANCIENT ISRAEL}

The influence of the ANE world on societies within the region in which ancient Israel was also a part cannot be taken for granted. Although the influence of ANE on Israel could largely have been cultural, one would envisage such influence to be also politico-economic as well as legal in character. For example, we read that the Babylonian Marduk, a thunderbolt wielding sun-weather god like Zeus in Greece, and Thor in Northern Europe, created a whole ordered universe over which he presided as a general policeman of Babylonian law and order. ${ }^{11}$ Thus, Amar Annus could not have said it better to annunciate that: "It seems reasonable to state that for ancient Mesopotamian societies the omens recorded in the compendia enjoys the status of the "laws' of the divine world order."12 Samuel Greengus (cited in Rodríguez) ${ }^{13}$ sheds more light in the following affirmation: "The similarity between the Israelite and pagan laws ${ }^{14}$ is remarkable and unexpected. The language in which the respective laws were formulated is at times so close that questions have arisen as to the originality and independence of the Israelite legislations." ${ }^{15}$ Greengus further notes that:

In the area of sexual prohibition, there are many similarities between biblical legislation and Hittite, Babylonian, and Assyrian laws.

10 See for example, Eben H. Scheffler, Fascinating Discoveries from the Biblical World (Pretoria: Biblia Publishers, 2000); Thomas Moser, "The Old Testament AntiUsury Laws Reconsidered: The Myth of Tribal Brotherhood," ETH/KOF Arbeitspapiere Nr. 49 (1997):1-9; Angel Manuel Rodríguez, "Ancient Near Eastern Parallels to the Bible and the Question of Revelation and Inspiration," Journal of the Adventist Theological Society 12/1 (2001):43-64; Jon L. Berquist, Judaism in Persia's Shadow: A Social and Historical Approach (Minneapolis: Fortress, 1995).

11 David A. Leeming, Creation Myths of the World: An Encyclopedia. Second Edition (California: Greenwood Publishers Group, 2010), 17.

12 Amar Annus, Divination and Interpretation of Signs in the Ancient World (Chicago: University of Chicago Press, 2010), 3.

13 See Samuel Greengus, "Law: Biblical and ANE Laws" in Anchor Bible Dictionary, 4:246 (ed. Noel Freedman; New York: Doubleday, 1992), 246; Rodríguez, "Ancient Near Eastern Parallels to the Bible and the Question of Revelation and Inspiration," 4364.

14 See "laws of the Medes and Persians" in Daniel 6:8, 12, 15 and 17.

15 See also W.J. Harrelson, "Laws in the OT" in Interpreter's Dictionary of the Bible (ed. George Arthur Buttrick; Nashville: Abingdon, 1992), 3:79. 
Interestingly, the biblical text states that the Egyptians and the Canaanites did not practise similar laws (Lev. 18:3, 27-29) but does not say anything about the Hittites, Babylonians and Assyrians. ${ }^{16}$

Following up on Greengus' assertion, Rodríguez makes the following comparison: "One law taken from Hammurabi 199 reads: 'If he destroys the eye of a citizen's slave or breaks the bone of the citizen's slave, he shall pay half of the purchasing price'. In the Exodus 21:26, we read that: 'If a man hits a manservant of maidservant in the eye and destroys it, he must let the servant go free to compensate for the eye." 17 In their own contribution in this regard, Victor H. Matthews and Don C. Benjamin pointed out that: "In the world of the Bible, the basis of law was not philosophy, but crisis. Lawgivers developed specific laws to deal with households which weakened or threatened the well-being of the state." 18 Matthews and Benjamin further made the following remarks: "...households weakened or threatened the well-being of the state when they failed to work their own land, feed their own children, and contribute to the cooperative efforts of the state to collect taxes and raise an army." ${ }^{19}$ Meanwhile, the observance of the law was paramount to the Israelite society (Lev. 24:22; Num. 6:13; Deut. 1:5, 6:25, 31:26; Josh. 1:8; 2 Kgs. 22:8; 2 Chron. 6:16, 17:9; Ezra 7:6; Neh. 8:2, 8:8; Psa. 1:2, 19:7; Prov. 29:18; Isa. 2:3, 8:20, 42:21; Jer. 8:8, 31:33; Micah 4:2; Hab. 1:7; Zech. 7:12; Matt. 5:17, 7:12). For Leeming: "The books of Genesis, Exodus, Leviticus, Numbers, and Deuteronomy are attributed to Moses' authorship."20 Underlying the biblical law (Exod. 23:3; Deut. 16:19$20)$ is the requirement that there should be no unjust offences between people. The law on keeping the Sabbath was one that the Israelites, even during the NT times (Pharisees and teachers of the law), emphasised from time to time. Rugwiji also maintained that: "It was overarching for Israel to keep the Sabbath (see Exod. 20:8-11; 31:14; 34:21; Lev. 25:2; Deut. 5:12-15; Am. 8:5; Jer. 17:21; Ezek. 20:12-24)."21 Thus, Rugwiji further penned that: "The Sabbath foreshadowed a time of relaxation." "22 Lawrence E. Browne had previously foregrounded that: "Babylonian strangers who came to Judaea would be accepted into all the privileges of Judaism, provided they kept the law of the

\footnotetext{
16 Greengus, "Law: Biblical and ANE Laws," 246.

17 Rodríguez, "Ancient Near Eastern Parallels to the Bible and the Question of Revelation and Inspiration," 53.

${ }^{18}$ Victor H. Matthews and Don C. Benjamin, Social World of Ancient Israel, 1250-587 BCE. (Peabody, MA: Hendrickson Publishers, 1993), 227.

19 Matthews and Benjamin, Social World of Ancient Israel, 227.

20 Leeming, Creation Myths of the World, 125.

21 Rugwiji, "Appropriating Judean Postexilic Literature in a Postcolonial Discourse," 67.

22 Rugwiji, “Appropriating Judean Postexilic Literature in a Postcolonial Discourse," 68.
} 
Sabbath." ${ }^{23}$ Circumcision was also one of the most important rituals in Judaism. Acknowledging Brown's study, Rugwiji affirms that: "Circumcision represented the covenant with Yahweh (Gen. 12:10-14)." 24 The same finding had previously been noted by John Goldingay as follows: "Circumcision was performed on men and it was mandatory that all Israelite males were circumcised" (Judg. 14:3; 15:18; 1 Sam. 14:6; 17:26, 36; 31:4; 2 Sam. 1:20; 1 Chron. 10:4). ${ }^{25}$

The law on cursing was circumstantial. According to Leviticus 19:14, the Israelites were forbidden to curse the deaf or put a stumbling block in front of the blind (Deut. 27:18). In Exodus 21:17, death penalty was prescribed for cursing one's parents: "Anyone who curses his father or mother must be put to death" (Lev. 20:9; Deut. 21:18-21; Prov. 20:20). ${ }^{26}$ Mark Mercer held that: "This is a logical extension of the commands to honour one's parents (Exod. 20:12; Lev. 19:3)." 27 One would be cursed for despising his father or mother (Deut. 27:16). Henceforth, Mercer further remarked that: "In Exodus 22:28b the Israelites were forbidden to "curse the ruler of your people"' (2 Sam. 16:9; 19:21; 1 Kings 2:8-9). ${ }^{28}$

Exodus 22:25 reads: "If you lend money to one of my people among you who are needy, do not be like a moneylender; charge him no interest..." Leviticus 25:36-37 concurs: "Do not take interest of any kind from him, but fear your God, so that your countrymen may continue to live among you. You must not lend him money or sell him food at a profit..." The question of land was also addressed by the OT laws. For example, Israel was warned against the selling of land (Lev. 25:23-38). The shifting of "ancient boundaries" (Deut. 19:14; 27:17; Job 24:2; Prov.22:28; 23:10; Hos. 5:10) was not condoned by the law. Hence, Proverbs teaches that: "Wealth obtained by fraud dwindles" (Prov. 13:11). Seizure of land or property which belonged to someone else was forbidden (Micah 2:2).

Ceremonial laws included sacrifices. For example, Paddy Musana acknowledged that: "According to the Mosaic Law, the firstlings of beasts, fruits and people were due to Yahweh" (Exod. 13:12; Lev. 27:26). ${ }^{29}$ Hence, Abraham's

23 Lawrence E. Browne, From Babylonia to Bethlehem (Cambridge: Heffer and Sons, 1951), 86.

24 Rugwiji, “Appropriating Judean Postexilic Literature in a Postcolonial Discourse," 74.

25 John Goldingay, "The Significance of Circumcision,” JSOT 88 (2000):4.

26 See Mark Mercer, "Elisha's Unbearable Curse: A Study of 2 Kings 2:23-25," African Journal of Evangelical Theology 21/1(2002): 187.

27 Mercer, "Elisha's Unbearable Curse," 187.

28 Mercer, "Elisha's Unbearable Curse," 187.

29 Paddy Musana, "The Judeo-Christian Concept of Sacrifice and Interpretation of Human Sacrifice in Uganda," International Letters of Social and Human Sciences 30/1 (2014):43. 
intention to sacrifice his son Isaac (Gen. 22), and Erikanah's and Hannah's dedication of the baby Samuel to the Lord at Shiloh (1 Sam. 1:24-28) were both in compliance with the demands of the law of the covenant. According to the Mosaic legislation, the material of the bloody sacrifice was taken from the personal possession of the worshipper, from among the clean animals (goats, sheep, and oxen). ${ }^{30}$

There were also laws which prohibited marriage of a younger girl ahead of the elder sister. For example, Laban gave Leah to Jacob as wife instead of Rachel whom Jacob loved because it was against the cultural custom of PadanAram that the younger daughter gets married first ahead of the elder daughter (Gen. 29:24-26). In numerous instances, cross-cultural relationships or marriages between Israel and the surrounding nations were prohibited (Deut. 7:1-4). For example, Jacob and his sons would not give Dinah as wife to Shechem, son of Hamor, of the city of Shechem because he was not circumcised (Gen. 34:13-16). For Jacob's sons to kill all the men of the city and take their sister Dinah was in compliance with the teaching of the law (Deut. 22:25). Jacob's sons were angry about such a disgraceful thing in Israel (Gen. 34:7).

Thus, some laws adopted and practised in ANE had something to do with matrimonial relationships. As Victor H. Matthews observes: "Jacob's daughter not showing the caution usually expected of tribal women, left encampment and was raped by the son of Hamor, the king of Shechem." ${ }^{31}$ According to Matthews: "The Middle Assyrian law codes, which date to the period of the 18th Century $\mathrm{BCE}$, provide parallel to this case. According to this legal code, an unbetrothed virgin could be obtained as a wife through forcible sexual relations." 32 Thus, as obtained from Matthews' study, "The man involved was obliged to marry the woman he had abused, and the king's son in this case was requested to do just that." 33 In our modern postbiblical context today, what is defined as "rape" of an unmarried virgin by a single man was actually normal in ANE. In my view, Jacob's refusal to let his daughter go was not necessarily on the basis of the abuse and or violation of his daughter; but that he disapproved of the marriage to a nonJew who was not circumcised. Hence, Matthews informs this study by affirming that: "The population of Shechem had to conform to the tribal custom of circumcision before marriage could take place." ${ }^{34}$ In another incident, Amnon raped his sister Tamar (2 Sam. 13:14). In compliance with the Jewish law (Deut.

30 Musana, "The Judeo-Christian Concept of Sacrifice," 43.

31 Victor H. Matthews, Manners and Customs in the Bible: An Illustrated Guide to Daily Life in Bible Times. Revised Edition (Peabody, MA: Hendrickson Publishers, 1991), 14.

32 Matthews, Manners and Customs in the Bible, 14.

33 Matthews, Manners and Customs in the Bible, 14.

34 Matthews, Manners and Customs in the Bible, 14. 
22:27), Tamar put some ashes on her head, and tore her long garments. With her hand on her head, she went out crying (2 Sam. 13:19). ${ }^{35}$

It is also believed that crucifixion ${ }^{36}$ as a form of punishing criminals and bandits was invented by the Persians and then practised also by the Assyrians, Phoenicians, Seleucids and Ptolemies. ${ }^{37}$ Zdravko Plantak affirmed that: "Justice as a basis of the law and the pillar of society was regarded by the prophets as binding for all ages." 38 Plantak further makes the following notation: "The guidance the prophets gave to Israel regarding social, ethical and economic relationships was clearly based on the Mosaic Law as expressed in the Ten Commandments." 39

It is also stated that the prophets played a central role of maintaining the Law of Moses. Joseph Blenkinsopp confirms the above view by stating the following: "The prophets continued the role and activity of Moses, the protoprophet" 40 . Hence, E. Mellor concurred that: "The prophets had several roles including being social, political and religious leaders who proclaimed the Law. Thus, the notion that Moses as the provider of the moral law becomes a standard of comparison for all other prophets" (Deut. 18:15). ${ }^{41}$ Roland De Vaux had already expressed a similar stance: "According to Deuteronomy 10:1-5, Moses built an Ark of acacia wood at Yahweh's command and put inside it the two stone tablets on which Yahweh had written the Ten Commandments." 42

In his recognition of previous researches, Thomas Römer writes that: "Since the majority of scholars abandoned the traditional documentary hypothesis, no new consensus has emerged about the formation of the Torah." 43 Although in numerous places in the biblical text the Judeans are depicted as absconding and disobeying Yahweh's command, they understood the Law of Moses as quintessential and the judgement of God as supreme. Postexilic

35 See Deuteronomy 22:27 one of the requirements when a virgin is raped.

36 The theme of crucifixion will be explored further when discussing the application of the OT laws in the NT.

37 Scheffler, Fascinating Discoveries from the Biblical World, 130.

38 Zdravko Plantak, "A Prophetic Community Today: Imaginative Visionaries and Social Activists for the Third Millennium" in Exploring the Frontiers of Faith: Festschrift in Honour of Dr Jan Paulsen - Congratulatory Edition (ed. Borge Schantz and Reinder Bruinsma. Lüneburg: Advent-Verlag, 2009), n.p.

39 Plantak, "A Prophetic Community Today."

40 J. Blenkinsopp, Sage, Priest, Prophet: Religious and Intellectual Leadership in Ancient Israel (Louisville, KY: Westminster John Knox Press, 1995), 120.

41 E. Mellor, Prophets and Poets (Nashville, TN: Abington Press, 1997).

42 Roland De Vaux, Ancient Israel: Its Life and Institutions (London: Darton, Longman \& Todd, 1973), 298.

43 Thomas Römer, "Moses outside the Torah and the Construction of the Diaspora Identity," Journal of Hebrew Scriptures 8/15(2008): 2. 
literature is also replete with law narratives. Other laws given to Moses and Aaron by Yahweh were dietary in form. Animals whose flesh could be eaten included cattle, sheep, goats, impala, and buffalo, among others. Animals and birds which should not be eaten included dead animals, pigs, vultures, and owls, among others (see Lev. 11; Deut. 14:3-21) ${ }^{44}$.

\section{E PAGAN KINGSHIP AND THE LAW}

In ancient Israel, a king was a political figure. In addition, a king also carried a spiritual and a social appendage. Menard Musendekwa, among others, reaffirms this viewpoint: "Through the king, the operation of the Spirit was applied, not to a purely miraculous sphere, but rather involving political, social and ethical dimensions." 45 However, sometimes kings would violate Yahweh's command and get punished for it even to the extent of losing the position of kingship. King Saul is one such king. According to 1 Samuel 13:8-14, Saul broke the law by performing a ritual of burnt offering which was the function of priests (1 Sam. 2:13-14). Because of such a violation, Saul's kingship was taken away from him and given to David. The sons of Eli, Hofni and Phinehas, also broke the law of priesthood by performing a ritual of burnt offering on the altar. As a result, they were killed in a battle against the Philistines (1 Sam. 2:11).

Now, considering the role of pagan kings in administering the law, Temba Rugwiji remarked: "Yahweh elects and anoints Cyrus, a pagan king, to set the Israelites free (Is 45:1-7)."46 Rugwiji's assertion borrows from an opinion that Eben H. Scheffler had advanced: "Cyrus' decree presaged the end of the Babylonian Empire and the liberation of the Judean exiles." ${ }^{47}$ Nevertheless, Mark L. Strauss, who is not unaware of the status quo, also adds that: "Yet, in actual fact, the political realities of the Persian period served to undermine the Judeans." 48 Such a shift has led other scholars, for example, Grabbe to conclude that: "By including a Persian in his agenda, Yahweh might have departed from his exclusive approach in order to make the Gentiles 'repent of their sins' by means of which Yahweh showed that his concern is not only for the welfare of

44 A detailed discussion on the animals and birds (to be eaten or not to be eaten) will be explored in a future research.

45 Menard Musendekwa, "Messianic Expectations as Prophetic Responses to Crises: A Zimbabwean Perspective" (MTh thesis, University of Stellenbosch, Cape Town, 2011), 6 .

46 Rugwiji, “Appropriating Judean Postexilic Literature in a Postcolonial Discourse," 3.

47 Eben H. Scheffler, "Reading the Bible in Context" in Ancient Israelite Literature in Context (eds. Willian Boshoff, Eben H. Scheffler and Izak Spangenberg; Pretoria: Protea, 2006), 144.

48 Mark L. Strauss, The Davidic Messiah in Luke-Acts: The Promise and its Fulfilment in Lukan Christology (Sheffield: Sheffield Academic Press, 1995), 38. 
Israel but also for that of the Gentiles." 49 In the same vein, Yamauchi suggests that: "Cyrus - like many other kings in the ancient near east_-believed in many gods." "50 Cyrus' belief in other gods (and not Yahweh) is substantiated by both James B. Pritchard and Amelie Kuhrt who provide detailed accounts of the clay cylinder (called the Cyrus Cylinder) on which Cyrus gave credit to the local god Marduk for enabling him to capture Babylonia. ${ }^{51}$ A similar proclamation was made by King Nebuchadnezzar (Dan. 4:29) and King Darius (Dan. 6:2-27) who respectively passed decrees commanding that everyone should worship no other gods but Yahweh. These actions, in my view, suggest that for Cyrus the temple was a strategic location for administering law and order in the province of Judea. Decrees were very important pieces of legislation in ANE.

Berquist is of the opinion that: "The codification of the native law, and the construction and maintenance of regional temples were most important

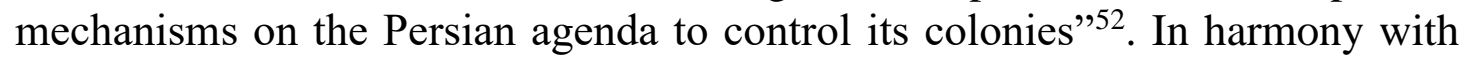
Berquist, Rugwiji concurs that: "No wonder the temple-building project in Judah was sponsored and financed by the Persian government, intended to "stretch out its arm" of control over the Judeans"53. Thus, Meanwhile, "The 'king's law,", observes Blum, "which Artaxerxes commissioned Ezra to administer in Yehud (Ezr 7:26) is likely associated with the Pentateuch, the canonised form of which was worked out in several stages during the Persian period." 54 Hence, Lemche present the Bible as a Hellenistic book. ${ }^{55}$ In almost the same line of thought as Lemche's viewpoint, Grabbe observed that: "The majority of the books that make up the present Hebrew canon were regarded as having religious authority by the end of the Persian period, thus arguing that the Bible is a Persian book."56 Rugwiji confirms that:

49 Lester L. Grabbe, Judaic Religion in the Second Temple Period: Belief and Practice from the Exile to Yavneh (London: Routledge, 2000), 18.

50 Edwin M. Yamauchi, "The Archaeological Background of Ezra," Bibliotheca Sacra 137 (1980):200.

51 James B. Pritchard, The Ancient near East in Pictures Relating to the Old Testament. (Princeton: Princeton University Press, 1954), 206-208; Amelie Kuhrt, "The Cyrus Cylinder and Achaemenid Imperial Policy," JSOT 25 (1983): 83-97.

52 Berquist, Judaism in Persia's Shadow, 147-159.

53 Rugwiji, "Appropriating Judean Postexilic Literature in a Postcolonial Discourse," 47.

54 Erhard Blum, Studien zur Komposition des Pentateuch (Berlin: Walter de Gruyter, 1990), 409-421; see also J. Blenkinsopp, The Pentateuch: An Introduction to the First Five Books of the Bible (New York: Doubleday, 1992), 239-242.

55 Niels Peter Lemche, "The Old Testament - A Hellenistic Book?" SJOT 7 (1993):163-193.

56 Lester L. Grabbe, A History of the Jews and Judaism in the Second Temple Period (London: T and T Clark, 2008), 247. 
The Persian Empire remained the administrative centre and law-enforcing authority across the province of Judea. The fact that they were required by law to pay tax to the Persian administration, depicts the notion of the Judeans having limited space of autonomy even though some of them were appointed as governors under the Persian Empire. Nehemiah 9:36-37 clearly states how the Judeans - among them Nehemiah himself-were subjected to slavery by the government. ${ }^{57}$

In Ezra 7:25, king Artaxerxes is depicted as making a decree that Ezra should "appoint magistrates and judges to administer justice to all the people of Trans-Euphrates - who know the laws of your God." Rugwiji further pens: "King Artaxerxes - acknowledging the Jewish law according to their traditionadvises Ezra to effect punishment as follows: 'Whoever does not obey the law of your God and the law of the king must surely be punished by death, banishment, confiscation of property, or imprisonment"' (Ezr 7:26, 10:8). ${ }^{58}$ In Ezra 6:11, we read that: "A beam shall be pulled out of the house of the perpetrator, who then shall be impaled on it. The house shall be made a dunghill". Matthews submits that: "At the traditional house of an Israelite was the threshold and doorway. Doors were first simply skin coverings, but these were eventually replaced by a more permanent wattle or wooden barrier and barred from within"59. Matthews further remarks that: "On the door post was placed a mezuzah which contained a fragment of the law and marked the family's adherence to the covenant." 60 Matthews adds that: "The threshold marked the legal entry way of the dwelling, and in some way has served as the place where justice was done (Deut. 22:21) or demanded (Judg. 19:27)."61 Meanwhile, reading Judges 17:6, indicates that there was some lawlessness in ancient Israel before the advent of the monarchy. For it reads: "In those days there was no king in Israel; all the people did what was right in their own eyes" (Judg. 17:6). Matthews reveals that: "Individual households and village assemblies administered justice and chose to listen or not to listen to the rallying calls of the judges". ${ }^{2}$ Matthews further notes that: "Beyond the level of the household, authority in the village was vested in the hands of the elders. These men, all

\footnotetext{
57 Rugwiji, “Appropriating Judean Postexilic Literature in a Postcolonial Discourse," 12.

58 Rugwiji, “Appropriating Judean Postexilic Literature in a Postcolonial Discourse," 70.

59 Matthews, Manners and Customs in the Bible, 49. Matthews' finding resonates with a similar practice among majority of the rural Shona people of Zimbabwe whose dagga thatched hut uses a wooden door that is fastened by a "chihuri" (a strong wooden plug) from inside to keep the door secure for safety purposes.

60 Matthews, Manners and Customs in the Bible, 49.

61 Matthews, Manners and Customs in the Bible, 49.

62 Matthews, Manners and Customs in the Bible, 67.
} 
heads of households and property owners, represented the collective wisdom of the community (Prov. 31:23)."63

\section{F THE FUNCTION OF THE LAW IN THE NT}

The applicability of the OT law to the NT and to Christians is questionable. ${ }^{64}$ Various instances exist which reveal that Christians were not bound by the Mosaic laws. For example, the NT is clear that Christians are not to curse others no matter who they are or what they have done. ${ }^{65}$ According to the legal tradition of the OT, for Christians to practise what is called "Holy Communion" or "The Lord's Supper" which involves red wine and bread as symbols of "blood" and "flesh" of Jesus, is actually breaching one of the OT laws (Gen. 9:4-5; Lev. 7:2627; Psa. 27:2; Zech. 11:9). Machingura and Museka reiterate that: "The Lord's Supper reflects the development of the Passover ritual in relation to the salvific blood covenant in Jesus' Last Supper where it became the central ritual of the Christian community which could be geographically celebrated repeatedly wherever and at any time." 66 In addition to not being under the Mosaic covenant and the Covenant curses that have fallen on ancient Israel, Christians cannot come under a curse from God because there are no injunctions in the NT commanding Christians to curse others. ${ }^{67}$ Mercer further mentioned of Paul telling Christians that: "Christ redeemed us from the curse of the law" (Gal. 3:13). ${ }^{68}$ Mercer went on to reaffirm that:

While the Mosaic law along with Scripture is 'useful for teaching, rebuking, correcting, and training in righteousness, so that the man of God may be equipped thoroughly, equipped for every good work ( 2 Tim. 3:16-17), Christians are not under jurisdiction of the law like Israel (Acts 15:5, 10-11, 28-29; 2 Cori. 3:3, 6-18; Gal. 3:3, 10-13; 5:1-6, 16-18; Col. 2:6-23; Heb. 8:8-9, 13). ${ }^{69}$

Meanwhile, Plantak had a different opinion. He presupposed that: "Christians need to abide by the OT laws" OT account of the moral law (Exod. 1-17; Deut. 5:1-22) and Jesus' elaboration of it (Matt. 5-7) require from people respect for and guarding of human rights. ${ }^{71}$ Thus, Plantak establishes the following:

\footnotetext{
63 Matthews, Manners and Customs in the Bible, 69.

64 Dorsey, "The Law of Moses and the Christians," 321.

65 Mercer, "Elisha's Unbearable Curse," 192.

66. Machingura and Museka, "'Blood as the Seat of Life,"” 48.

67 Mercer, "Elisha's Unbearable Curse," 194.

68 Mercer, "Elisha's Unbearable Curse," 194.

69 Mercer, "Elisha's Unbearable Curse," 193.

70 Plantak, "A Prophetic Community Today."

71 Plantak, "A Prophetic Community Today."
} 
Considering that God is interested in relationships between human beings and that he demonstrated the desire to regulate these relationships with the last six commandments of the Decalogue and with numerous sayings of Jesus, the body of Christ today (i.e. his embodied a) should uplift these regulations and apply them to everyday life. ${ }^{72}$

Plantak also advanced the opinion that: "For a full understanding of what God means by his moral law, a Christian must turn to God Incarnate"73. Plantak then mentioned Jesus' remarkable sermon on the law that he did not come to abolish the law, but to fulfil it (Matt. 5:17). ${ }^{74}$ Additionally, Plantak reiterates Jesus stating that: "Anyone who breaks one of the least of these commandments and teaches others to do the same will be called the least in the Kingdom of Heaven; but whoever practices and teaches these commands will be called great in the Kingdom of Heaven" (Matt. 5:19). ${ }^{75}$ In fact, the NT portrays the view that Jesus was not only inclined towards breaking the OT Law, but also the law as enforced in the Roman Empire as a whole. It is argued elsewhere that the tendency of breaking the law motivated Jesus' crucifixion. Jesus' disciples were believed to be armed. For example, Jesus urged his disciples that: "... But now if you have a purse, take it, and also a bag; and if you don't have a sword, sell your cloak and buy one" (Luke 22:36). With that view in mind, Rome could have interpreted Jesus" "movement" as politically dangerous. ${ }^{76}$ During the first century BCE, the Romans employed crucifixion not so much towards Roman citizens, but towards foreign slaves convicted of crimes, political captives, rebels or fugitives. ${ }^{77}$

Although Jesus claimed that he did not come to obliterate the OT laws and the prophets, but to fulfil them (Matt.5:17) which is also demonstrated by his encouragement towards the payment of tax (Matt. 22:15-22; Mark 12:13-17; Luke 20:20-26), there are numerous places in the NT where Jesus actually disagreed with the teachings of the Law. For example, his response to the question of breaching the Sabbath regulations by the disciples (Matt. 12:1-8), his healing of a man with a withered hand on the Sabbath (Matt. 12:9-14), and his refuting of the "law of Moses" regarding the letter of divorce (see Deut. 24:1; Matt. 5:31-32; 19:1-10). Joseph discovered that Mary was pregnant "and not willing to disgrace her openly, intended to send her away openly" (Matt. 1:19). Joseph particularly intended to protect Mary from death by stoning because

\footnotetext{
72 Plantak, "A Prophetic Community Today."

73 Plantak, "A Prophetic Community Today."

74 Plantak, "A Prophetic Community Today."

75 Plantak, "A Prophetic Community Today."

76 See Paula Fredriksen, "Arms and the Man: A Response to Dale Martin's 'Jesus in Jerusalem: Armed and not Dangerous," Journal for the Study of the New Testament 37/3 (2015):312.

77 Scheffler, Fascinating Discoveries from the Biblical World, 130.
} 
according to Deuteronomy 22:20-21, if a girl was found to have lost her virginity, she was to be dragged outside the home and men of the city would stone her to death". The same kind of punishment would be exerted on a woman who was caught in the act of adultery. The Pharisees and the Scribes brought the woman to Jesus saying, "In the law, Moses commanded us to stone such women. What then do you say?" (John 8:5). Luckily, this particular woman was saved by Jesus (John 8:11). Jesus' response demonstrates that not in all cases that OT laws would apply among postbiblical societies. Even that of losing virginity by the girl child, as the OT law commands, Christians would be the first ones to either divorce the bride or order her death by stoning, but who would do that in a postmodern society in which violation of human rights must be condemned? Even though most Christians accept the authority of the Bible, ${ }^{78}$ the OT laws cannot be used by the political leadership in a modern postbiblical world because it will mean the church taking control of the justice system on behalf of a constitutionally-elected government. However, during OT times, there were instances in which some offences were tried at local community levels especially where Judaism was considered as representing the majority. Hence, Pilate handed over Jesus to the Jews to be crucified (Luke 23:25). But, why would the Jews seek Pilate's approval to have Jesus crucified? Surely, they had Jesus the whole night after they arrested him at the Mount of Olives (Luke 22:54). The answer to the above question is that lawfulness (or lawlessness) remains implied when not adjudicated by a superior who has a constitutional mandate to do so. Meanwhile, Pilate's handing over Jesus to be tried and executed by a Jewish community was also unconstitutional. ${ }^{79}$ In addition, the Bible is silent about Pilate making efforts towards informing the Jewish crowd on the implications of the law if they went ahead to execute Jesus. This implies that the final decision to execute or not was not necessarily based on the justice system in general or legislation; it was leveraged on personal judgment. If what is depicted in the biblical text is credible about Pilate conceding to the demands of the Jewish communities, the punishment of Jesus through crucifixion was not only grossly unjustified, but also criminal.

When John the Baptizer rebuked King Herod that: "It is unlawful for you to have the wife of your brother" (Mark 6:18), John demonstrated his familiarisation with the teaching of the law as stipulated in Leviticus 18:16 and 20:21. However, King Herod --as is the deliberate practice with many people in positions of power to break the law--not only broke this law of marrying his younger brother's wife, but also that of murder (Exod. 20:13) because we read that: "And immediately the king sent a guard and ordered him to bring his

78 Maarten Wisse, "The Meaning of the Authority of the Bible," Religious Studies 36/4(2000): 473.

79 The unconstitutionality of handing over Jesus to the Jews will be explored in a future study. 
(John's $\left.{ }^{80}\right)$ head. And he went out and beheaded him $\left(\mathrm{John}^{81}\right)$ in prison" (Mark 6:27).

Two important factors may be noted in the narrative about Herod and John. First, it can be presupposed that for John to remind Herod about the legal requirement against marrying the wife of his younger brother suggests that John was aware that Herod was also bound by such legislation. It was unreasonable for John to challenge the king about the law that was only practised by the Jews. Second, it was not an offence of treason which John committed for Herod to send him to prison. In my view, Herod understood quite well that the legal contestation that John was raising had serious implications on the king's position because perhaps Herod himself was a participant in the formulation, composition and implementation of such a law. I therefore argue that for Herod to plot the death of John the Baptizer was intrinsically on the basis of the king being conscious of the consequences of breaking the law. The question of Herod going ahead in marrying his younger brother's wife without any hindrance was not fundamentally the reason for eliminating John for making reference to the OT law which prohibited the king to marry his younger brother's wife.

The Apostle Paul, whose gospel is described as "law-free," 82 also sees the OT laws without meaning if not accompanied by love. Paul says: "Love fulfils the law" (Rom. 13:8). He goes on to say, "Laws such as: do not commit adult, do not kill, do not steal, do not covet, or any law, all are summarised in the statement that says: "Love your neighbour as yourself"" (Rom. 13:9). Paul demonstrates his familiarity with one of the laws in the Decalogue which says: "You shall kill" (Exod. 20:13). ${ }^{83}$ In the NT, the law of circumcision does not merit as rigid a span of attention as it does in the OT.

As already noted in this essay, not every OT law is being practised by postbiblical societies. For example, pork meat (pig) is liked by many Christians. One wonders whether Jesus' response to the question of his disciples' eating without washing hands (Mark 7:2) would not apply to animals designated as "unclean". Jesus answered that: "There is nothing outside of a man which entering into him can defile him, but the things coming out of a man are things which defile a man" (Mark 7:15). An anonymous informant has revealed to me that during the economic crisis of 2008 in Zimbabwe, some people were seen

\footnotetext{
80 Insertion is mine.

81 Insertion is mine.

82 David C. Sim, "Are the Least Included in the Kingdom of Heaven? The Meaning of Matthew 5:19," HTS 54/3\&4 (1998):573-587; see also Yolanda Dreyer, "Son-ofGod Traditions in the Synoptic Gospels: Ferdinand Hahn's Diachronic Perspective," HTS 57/1\&2(2001):512.

83 See Alpheus M. Masoga and Temba Rugwiji, "A Reflection on Ritual Murders from an African Perspective," Scriptura 117/1 (2018):2.
} 
feasting on monkey meat and horse carcases! Another gossip also says some societies in Botswana and China, especially, are fond of donkey, dog and cat meat. However, for those not familiar with OT law narratives, these dietary laws may not apply. But for Jews, the law forbids it.

\section{G CONCLUSIONS}

This study has explored the OT law traditions in view of three research questions, namely: (1) how were the OT laws formulated and implemented? (2) Were the OT laws the same as those practiced by pagan nations or kings? (3) what is the NT/Christian view of the OT laws? It was illustrated by way of examples that OT laws were not unique to Israel because other societies of ANE (e.g. Babylonians, Hittites and Assyrians, among others) also ratified their own religio-cultural traditions in which various laws were formulated and documented. The striking similarities between the laws of other societies in ANE and Israel's/OT laws have generated some interests for some scholars to suspect that some borrowing of traditions might have occurred in ANE. The question is: who borrowed from who?

However, it was discovered that the OT law narratives depict that the ancient Israelite society was a law-abiding society which was validated by the formulation and implementation of civic, ceremonial and moral laws. The ancient Israelite society held the Torah as the Law from Yahweh and the accompanying laws were given to humanity for posterity. It was explored that pagan kings incorporated OT laws into their corpus of "secular" laws. For example, in Persia, Cyrus believed that he was anointed by Yahweh to be the liberator of the Judeans from Babylonian exile. Cyrus passed a decree (a rule) that the Judeans return to Yehud. Hence, when Judea became a province of the Persian Empire, the temple became the centre of administration for Persia. Other examples which were cited include Nebuchadnezzar and Darius who--in their individual capacities--also proclaimed decrees to the entire nation that Yahweh, the God of Israel, should be worshipped.

The importance of OT laws for modern societies outside Israel is ratified by the appropriation of some of the laws of ancient Israel in a contemporary context. Divergent opinions have also been noted in terms of both adoption and practicality of the OT laws among Christians. Meanwhile, examples were drawn from the NT where personages such as Jesus and Paul either disagreed with or outlawed the OT legal tradition. The study argued that although the Torah and the other OT books are regarded by Christians as authoritative, the conveyance of the biblical laws is not adhered to in practice. Few examples were cited of Christians who eat pork meat, no death penalties for people caught in the act of adultery, and individuals who lost their virginity are not killed. In the contextual usage of the OT laws, relevant penalties would be implemented for such offences. 
This study concludes by averring that Christians superficially believe with a high level of pretence and dishonesty the teachings of the OT laws because their subconsciousness informs them of the obviousness of the full wrath of the law for human rights violation if some conflicting OT laws are implemented in our contemporary context. The employment of the phrase the "Bible says" poses a very serious challenge for non-Christians and the readership in general. The claim that OT laws are applicable in the church is not only exaggerated, but also depicts some sense of selectivity by individuals who are at liberty to apply certain OT laws and avoid others whenever and wherever it is convenient for them to do so.

\section{BIBLIOGRAPHY}

Alt, Albrecht. "The Origin of Israelite Law," in Essays on Old Testament History and Religion, 79-132. Oxford: Oxford University Press, 1996.

Anderson, Cheryl B. Ancient Laws and Contemporary Controversies. Oxford University Press, 2009. https://doi.org/10.1093/acprof:oso/9780195305500.001 .0001 .

Annus Amar. Divination and Interpretation of Signs in the Ancient World. Chicago: University of Chicago Press, 2010.

Berquist, L. Jon. Judaism in Persia's Shadow: A Social and Historical Approach. Minneapolis: Fortress, 1995.

Blenkinsopp, Joseph. Sage, Priest, Prophet: Religious and Intellectual Leadership in Ancient Israel. Louisville, KY: Westminster John Knox Press, 1995.

Blenkinsopp, Joseph. The Pentateuch: An Introduction to the First Five Books of the Bible. New York: Doubleday, 1992.

Blum, Erhard. Studien zur Komposition des Pentateuch. Berlin: Walter de Gruyter, 1990. https://doi.org/10.1515/9783110879506.

Browne, Lawrence E. From Babylonia to Bethlehem. Cambridge: Heffer and Sons, 1951.

Burnside, Jonathan. God, Justice and Society: Aspects of the Law and Legality in the Bible. Oxford: Oxford University Press, 2011.

De Vaux, Roland. Ancient Israel: Its Life and Institutions. London: Darton, Longman \& Todd, 1973.

Dorsey, David. "The Law of Moses and the Christians: A Compromise." JETS 34/3(1991): 321-334.

Dreyer, Yolanda. "Son-of-God Traditions in the Synoptic Gospels: Ferdinand Hahn's Diachronic Perspective." HTS 57/1\&2(2001): 506-530. https://doi.org/10.4102/ hts.v57i1/2.1878.

Fredriksen, Paula "Arms and the Man: A Response to Dale Martin's 'Jesus in Jerusalem: Armed and not Dangerous." Journal for the Study of the New Testament 37/3(2015): 312-325.

Goldingay, John. "The Significance of Circumcision." JSOT 88 (2000): 3-18. https://doi.org/10.1177/030908920002508801.

Grabbe, L. Lester. A History of the Jews and Judaism in the Second Temple Period. London: T and T Clark, 2008.

Grabbe, L. Lester. Judaic Religion in the Second Temple Period: Belief and Practice from the Exile to Yavneh. London: Routledge, 2000. 
Greengus, Samuel. "Law: Biblical and ANE Laws." Page 4:246 in Anchor Bible Dictionary, Edited by Noel Freedman. New York: Doubleday, 1992.

Harrelson, W.J. 1992. "Laws in the OT". Interpreter's Dictionary of the Bible, 3:79. Edited by George Arthur Buttrick. Nashville: Abingdon.

Hiers, Richard H. Justice, and Compassion in the Biblical Law. Bloomsbury: T\&T Clark, 2009.

Kuhrt, Amelie. "The Cyrus Cylinder and Achaemenid Imperial Policy." JSOT 25 (1983): 83-97. https://doi.org/10.1177/030908928300802507.

Leeming, David A. Creation Myths of the World: An Encyclopedia. Second Edition. California: Greenwood Publishers Group, 2010.

Lemche, Niels Peter. "The Old Testament - A Hellenistic Book?" SJOT 7 (1993): 163193. https://doi.org/10.1080/09018329308585016.

Machingura, Francis and Museka, Godfrey. "Blood as the Seat of Life': The Blood Paradox among Afro-Christians." Perichoresis 14/1(2016): 41-62. https://doi. org/10.1515/perc-2016-0003.

Masoga, Alpheus M. and Rugwiji, Temba. "A Reflection on Ritual Murders from an African Perspective." Scriptura 117/1 (2018): 1-13.

Matthews, Victor H. Manners and Customs in the Bible: An Illustrated Guide to Daily Life in Bible Times. Revised Edition. Peabody, MA: Hendrickson Publishers, 1991.

Matthews, Victor. H. and Benjamin, Don C. Social World of Ancient Israel, 1250-587 BCE. Peabody, MA: Hendrickson Publishers, 1993.

Mellor, E. Prophets and Poets. Nashville, TN: Abington Press, 1997.

Mercer, Mark. "Elisha's Unbearable Curse: A Study of 2 Kings 2:23-25." African Journal of Evangelical Theology 21/1(2002): 166-198.

Moser, Thomas. "The Old Testament Anti-Usury Laws Reconsidered: The Myth of Tribal Brotherhood." ETH/KOF Arbeitspapiere Nr. 49 (1997): 1-9. https://doi.org/10.2139/ssrn.41844.

Musana, Paddy. "The Judeo-Christian Concept of Sacrifice and Interpretation of Human Sacrifice in Uganda." International Letters of Social and Human Sciences 30/1 (2014): 39-52 https://doi.org/10.18052/www.scipress.com/ILSHS.41.39.

Musendekwa, Menard. "Messianic Expectations as Prophetic Responses to Crises: A Zimbabwean Perspective." MTh thesis, University of Stellenbosch, Cape Town, 2011.

Plantak, Zdravko. "A Prophetic Community Today: Imaginative Visionaries and Social Activists for the Third Millennium." No pages in Exploring the Frontiers of Faith: Festschrift in Honour of Dr Jan Paulsen - Congratulatory Edition. Edited by Borge Schantz and Reinder Bruinsma. Lüuneburg: Advent-Verlag, 2009.

Pritchard, B. James. The Ancient near East in Pictures Relating to the Old Testament. Princeton: Princeton University Press, 1954. https://doi.org/10.1515/9781400 $\underline{882762 .}$.

Rodríguez, Angel Manuel. "Ancient Near Eastern Parallels to the Bible and the Question of Revelation and Inspiration." Journal of the Adventist Theological Society 12/1 (2001): 43-64.

Römer, Thomas. "Moses outside the Torah and the Construction of the Diaspora Identity." Journal of Hebrew Scriptures 8/15(2008): 2-12. https://doi.org/10.5508 /jhs.2008.v8.a15. 
142 Rugwiji, “The Law and Society” OTE 33/1 (2020): 125-142

Rugwiji, Temba. "Appropriating Judean Postexilic Literature in a Postcolonial Discourse: A Case for Zimbabwe.” PhD thesis, University South Africa, Pretoria, 2013

Scheffler, Eben H. "Reading the Bible in Context." Pages 11-17 in Ancient Israelite Literature in Context. Edited by Willem Boshoff, Eben H. Scheffler and Izak Spangenberg. Pretoria: Protea, 2006.

Scheffler, Eben H. Politics in Ancient Israel. Pretoria: Biblia Publishers, 2001.

Scheffler, Eben H. Fascinating Discoveries from the Biblical World. Pretoria: Biblia Publishers, 2000.

Sim, David C. "Are the Least Included in the Kingdom of Heaven? The Meaning of Matthew 5:19." HTS 54/3\&4(1998): 573-587. https://doi.org/10.4102/hts.v54i3/ 4.1431.

Strauss, L. Mark. The Davidic Messiah in Luke-Acts: The Promise and its Fulfilment in Lukan Christology. Sheffield: Sheffield Academic Press, 1995.

Swanson, Dennis M. "Introduction to New Covenant Theology." TMSJ 18/1 (Fall 2007): 149-163.

Westbrook, Raymond \& Wells, Bruce. Everyday Law in the Biblical Israel: An Introduction. Westminster: John Knox Press, 2009.

Wisse, Maarten. "The Meaning of the Authority of the Bible." Religious Studies 36/4 (2000): 473-487. https://doi.org/10.1017/S0034412500005400.

Yamauchi, M. Edwin. "The Archaeological Background of Ezra." Bibliotheca Sacra 137 (1980): 195-211.

Zaspel, Fred G. "Divine Law: A New Covenant Perspective." Reformation and Revival 6/3 (Summer 1997):145-69.

Temba T. Rugwiji, Department of Old Testament Studies, University of Pretoria, South Africa. Email: rugwiji1964@gmail.com ORCID: https://orcid.org/00000002-9080-9908. 